\title{
FACTORS INFLUENCING THE EXCHANGE OF SODIUM BETWEEN PLASMA AND CEREBROSPINAL FLUID * $\dagger$
}

\author{
By ROBERT A. FISHMAN \\ (From the Department of Neurology, College of Physicians and Surgeons, Columbia Uni- \\ versity, the Neurological Institute, Presbyterian Hospital, and the New York State \\ Psychiatric Institute, New York, N. Y.)
}

(Submitted for publication April 28, 1959; accepted June 19, 1959)

This study is concerned with the mechanism of exchange of sodium between plasma and cerebrospinal fluid (CSF). Several workers $(1,2)$ have reported that there is no significant difference between the concentration of sodium in plasma and CSF. Merritt and Fremont-Smith (3) reported that the average concentration of sodium in CSF, in man, exceeded the plasma concentration by about four mEq. Davson (4) has determined the distribution ratio of sodium between CSF and plasma as 0.975 in the dog, correcting for the difference in water content of these fluids. Despite the similarity in sodium concentration of these fluids and the superficial resemblance of CSF to a protein-free filtrate of plasma, intravenously administered radio-sodium reaches equilibrium in the CSF far more slowly than in the extracellular fluid $(5,6)$. The delay in exchange between plasma and CSF has been attributed to the existence of a blood-CSF barrier for sodium (5-7). The present experiments have been devised to note the effect of a variety of physiological and pharmacological alterations on the exchange of sodium between these fluid compartments.

\section{METHODS}

One hundred and twenty-three experiments were performed in 27 adult mongrel dogs anesthetized with intravenously administered sodium pentobarbital (30 mg. per Kg.). Additional doses of pentobarbital were given intravenously during the experiment to maintain a stable corneal reflex and respiratory rate. Sixty to 80 microcuries of $\mathrm{Na}^{24}$ was administered intravenously. Samples of serum and $0.6 \mathrm{ml}$. samples of cisternal fluid were removed successively at the end of five or six 45 minute

* This work has been supported in part by grants from the National Multiple Sclerosis Society and the Dysautonomia Association, Inc.

+ A preliminary report was presented at the annual meeting of the American Neurological Association in 1957. intervals. The time necessary for the activity of the cisternal fluid to reach 50 per cent of the serum activity was obtained by graphic analysis of the CSF/serum ratios at these time intervals. As the serum radioactivity was not maintained at a constant level, a time constant was not calculated but the half-time as determined was used as the measure of the rate of sodium exchange. This half-time is referred to as the sodium exchange time. A typical experiment is illustrated in Figure 1. Radioactivity was measured in duplicate with a welltype scintillation counter and sodium content with a flame photometer. Each animal had at least one control study in addition to one or more experimental studies. Each animal was given at least a seven day recovery period between experiments. Cisternal fluid pressure, when required, was measured with a spinal water manometer. Blood pressure was recorded in some experiments with a strain-gage manometer.

\section{RESULTS}

I. Concentration of sodium in serum and cerebrospinal fluid of normal dogs

The serum and CSF sodium concentrations were determined in 27 normal dogs. The average serum sodium concentration was $155 \pm 6 \mathrm{mEq}$. per $\mathrm{L}$. The average CSF sodium concentration was $158 \pm 6 \mathrm{mEq}$. per L. Statistical analysis using Student's " $t$ " test (8) for correlated means revealed no significant difference between these values $(p>0.2)$. The serum and CSF sodium concentrations were not significantly altered in any of the experiments. The serum sodium varied between 142 and $166 \mathrm{mEq}$. per L. and the CSF sodium between 144 and $168 \mathrm{mEq}$. per L. The difference in concentration of sodium in the CSF varied between +9 and $-4 \mathrm{mEq}$. per L. as compared to the serum. The concentrations may be expressed as corrected for the differences in water content of serum and CSF. Assuming the water content of serum to be 92 per cent, and of CSF to be $99^{\circ}$ per cent (7), the average concentration in plasma is $168 \mathrm{mEq}$. per $\mathrm{Kg}$. of water, 


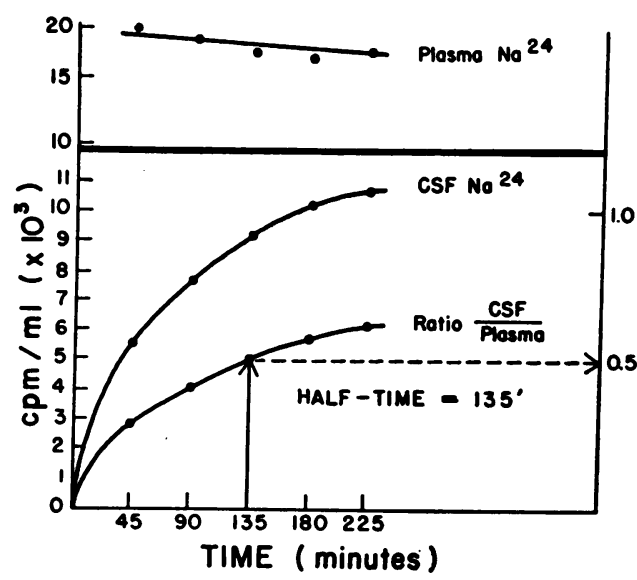

Fig. 1. Control Study: Dog $\mathrm{BO}_{1}$

A typical experiment illustrating the determination of sodium exchange time in a normal control study.

and that of CSF is $159 \mathrm{mEq}$. per $\mathrm{Kg}$. of water. The assumed distribution ratio would be 0.95 .

\section{Sodium exchange time in normal dogs}

The average sodium exchange time in 27 normal dogs was $143 \pm 38$ minutes (S.D.), with a range of 90 to 260 minutes. The control study was repeated in 10 dogs at least one week after the initial study. The data are summarized in Table I. The mean difference between the paired control studies was $+3.0 \pm 17.0$ minutes. The mean difference of +3.0 was found to be not significantly different statistically from zero at the .01 level of significance, by Student's " $t$ " test (8). In subsequent experiments, the effect of the various drugs and procedures on the sodium exchange

TABLE I

Sodium exchange time in normal dogs: Duplicate studies

\begin{tabular}{cccc}
\hline \hline Dog & $\begin{array}{c}\text { First } \\
\text { study }\end{array}$ & $\begin{array}{c}\text { Second } \\
\text { study }\end{array}$ & Difference \\
\hline & min. & min. & min. \\
BO & 135 & 160 & +25 \\
CU & 260 & 275 & +15 \\
UG & 115 & 85 & -30 \\
NO & 200 & 210 & +10 \\
XE & 125 & 125 & 0 \\
NA & 110 & 130 & +20 \\
WA & 95 & 95 & -5 \\
AT & 130 & 125 & -15 \\
FL & 140 & 125 & +10 \\
& 140 & 150 & +10 \\
& & Mean difference & $+3.0 \mathrm{~min}$. \\
& & S.D. & $\pm 17.0 \mathrm{~min}$.
\end{tabular}

time was tested and analyzed statistically by Wald's method of sequential analysis (9). The standard deviation of differences in half-time during the control and experimental studies was assumed to be twice as large as the standard deviation of differences in half-time on duplicate control readings. The upper limit of the 90 per cent confidence interval for the true standard deviation of differences in half-time on duplicate control readings was taken as the estimate of the true standard deviation. The data are summarized in Table II.

\section{Factors altering sodium exchange time (see Table II)}

1. Vasopressin. The effect of vasopressin on the sodium exchange time was determined in six dogs. Four dogs were given intravenously 2 to 5 units of vasopressin per $\mathrm{Kg}$. of body weight. Two dogs were given intravenously 5 units per $\mathrm{Kg}$. of body weight and each an additional 3 units and 5 units per $\mathrm{Kg}$. by intramuscular route. The intramuscular doses were divided so that 1 unit and 1.7 units respectively were given at the end of the first, second and third 45 minute intervals. A dosage of 2 units per $\mathrm{Kg}$. of body weight did not alter the control time. Dosages of 5 units per $\mathrm{Kg}$. of body weight resulted in a statistically significant decrease in sodium exchange time. No statistical statement can be made about the animals receiving a total of 8 and 10 units per $\mathrm{Kg}$., respectively, but the data are interpreted to illustrate also an effect at the higher dosage levels. The difference between the control and experimental half-times in the five animals receiving the higher dosages varied between a decrement of 45 and 75 minutes. The fall in half-time varied between 35 per cent and 85 per cent of the control values in these animals.

Such large dosages of vasopressin have a significant effect on the blood pressure. Vasopressin, 5 units per $\mathrm{Kg}$. of body weight, given intravenously, results in an acute elevation of the mean arterial blood pressure of 50 to 74 per cent above its resting level which is sustained for about 10 minutes. It gradually drops to its initial value at the end of one hour. The CSF has a parallel increase and subsequent fall in pressure. To ascertain whether the vasopressin effect on 
TABLE II

Summary of control and experimental sodium exchange times and their differences

\begin{tabular}{|c|c|c|c|c|}
\hline Experiment & Dog & $\begin{array}{c}\text { Control } \\
\text { half-time }\end{array}$ & $\begin{array}{l}\text { Experimental } \\
\text { half-time }\end{array}$ & Difference \\
\hline Vasopressin & & $\min$. & $\min$. & $\min$. \\
\hline $\begin{array}{l}2 \text { units/Kg. i.v. } \\
5 \text { units/Kg.*i.v. } \\
5 \text { units/Kg. i.v. } \\
5 \text { units/Kg. i.v. } \\
8 \text { units/Kg. (5 units/Kg. i.v.) }\end{array}$ & $\begin{array}{l}\text { RO } \\
\text { WA } \dagger \\
\text { CLL } \\
\text { OL } \\
\text { RO }\end{array}$ & $\begin{array}{r}95 \\
130 \\
155 \\
95 \\
95\end{array}$ & $\begin{array}{l}95 \\
85 \\
90 \\
35 \\
45\end{array}$ & $\begin{array}{r}0 \\
-\quad 45 \\
-\quad 65 \\
=\quad 60 \\
-\quad 50\end{array}$ \\
\hline 10 units $/ \mathrm{Kg} .\left(\begin{array}{l}5 \text { units } / \mathrm{Kg} . \text { i.v.) } \\
(5 \text { units/Kg. i.m.) }\end{array}\right.$ & FA & 130 & 55 & -75 \\
\hline $\begin{array}{l}\text { Acetazolamide } \\
30 \mathrm{mg} . / \mathrm{Kg} \cdot \\
50 \mathrm{mg} \cdot / \mathrm{Kg} \cdot \\
100 \mathrm{mg} \cdot / \mathrm{Kg} \cdot \\
100 \mathrm{mg} \cdot / \mathrm{Kg}^{*} \\
120 \mathrm{mg} . / \mathrm{Kg}^{*} \\
\text { Mass lesion* } \\
\text { CSF drainage* }\end{array}$ & $\begin{array}{l}\text { XE } \\
\text { UG } \\
\text { BO } \\
\text { OL } \\
\text { FA } \\
\text { PL } \\
\text { CH } † \\
\text { CH } \\
\text { FO }\end{array}$ & $\begin{array}{r}125 \\
115 \\
135 \\
95 \\
130 \\
150 \\
175 \\
175 \\
135\end{array}$ & $\begin{array}{r}245 \\
185 \\
250 \\
225 \\
220 \\
60 \\
120 \\
90 \\
110\end{array}$ & $\begin{array}{l}+120 \\
+70 \\
+115 \\
+130 \\
+90 \\
-90 \\
-55 \\
-85 \\
-25\end{array}$ \\
\hline $\begin{array}{l}50 \% \text { sucrose } \\
1.5 \mathrm{ml} . / \mathrm{Kg} . \\
3.0 \mathrm{ml} . / \mathrm{Kg} . \\
3.0 \mathrm{ml} . / \mathrm{Kg} . \\
5.0 \mathrm{ml} . / \mathrm{Kg} . \\
7.0 \mathrm{ml} . / \mathrm{Kg} \text {. } \\
5 \% \text { dextrose } / \text { water }\end{array}$ & $\begin{array}{l}\text { XE } \\
\text { BO } \\
\text { XE } \\
\text { FU } \\
\text { XE }\end{array}$ & $\begin{array}{l}125 \\
135 \\
125 \\
160 \\
125\end{array}$ & $\begin{array}{l}140 \\
135 \\
150 \\
148 \\
135\end{array}$ & $\begin{array}{r}+15 \\
+\quad 25 \\
+12 \\
+10\end{array}$ \\
\hline $\begin{array}{l}50 \mathrm{ml} . / \mathrm{Kg} \text {. } \\
50 \mathrm{ml} . / \mathrm{Kg} . \\
50 \mathrm{ml} . / \mathrm{Kg}\end{array}$ & $\begin{array}{l}\text { CL } \\
\text { XE } \\
\text { WA }\end{array}$ & $\begin{array}{l}155 \\
125 \\
130\end{array}$ & $\begin{array}{l}125 \\
125 \\
150\end{array}$ & $\begin{array}{r}-30 \\
+\quad 0 \\
+\quad 20\end{array}$ \\
\hline $\begin{array}{l}\text { Steroids } \\
\text { DCA }\end{array}$ & & & & \\
\hline $\begin{array}{l}2 \mathrm{mg} . / \mathrm{Kg} .(2, \text { in } 20 \mathrm{hrs} .) \\
2 \mathrm{mg} . / \mathrm{Kg} . \text { (daily, } 11 \text { days) } \\
\text { Cortisone }\end{array}$ & $\begin{array}{l}\mathrm{BL} \\
\mathrm{BL}\end{array}$ & $\begin{array}{l}145 \\
145\end{array}$ & $\begin{array}{l}145 \\
140\end{array}$ & $\begin{array}{r}0 \\
-\quad 5\end{array}$ \\
\hline $\begin{array}{l}7.5 \mathrm{mg} . / \mathrm{Kg} . \text { (2, in } 20 \mathrm{hrs} \text { ) } \\
7.5 \mathrm{mg} / \mathrm{Kg} \text {. (daily, } 14 \text { days) } \\
\text { ACTH }\end{array}$ & $\begin{array}{l}\text { WO } \\
\text { BL }\end{array}$ & $\begin{array}{l}170 \\
145\end{array}$ & $\begin{array}{l}165 \\
160\end{array}$ & $\begin{array}{l}5 \\
+ \\
15\end{array}$ \\
\hline $\begin{array}{l}2 \text { units } / \mathrm{Kg} \text {. (daily, } 12 \text { days) } \\
10 \% \text { carbon dioxide }\end{array}$ & $\mathrm{TA}$ & 215 & 235 & +20 \\
\hline $\begin{array}{l}0.5 \mathrm{~L} . / \mathrm{Kg} . / \mathrm{min} . \\
0.5 \mathrm{~L} . / \mathrm{Kg} . / \mathrm{min} . \\
0.5 \mathrm{~L} . / \mathrm{Kg} . / \mathrm{min} . \\
\text { Norepinephrine }\end{array}$ & $\begin{array}{l}\text { TA } \\
\text { FA } \\
\text { CL }\end{array}$ & $\begin{array}{l}215 \\
130 \\
155\end{array}$ & $\begin{array}{l}225 \\
155 \\
140\end{array}$ & $\begin{array}{l}+10 \\
+25 \\
-15\end{array}$ \\
\hline $\begin{array}{l}0.25 \mathrm{mg} \cdot / \mathrm{Kg} . \\
0.25 \mathrm{mg} \cdot / \mathrm{Kg} . \\
0.25 \mathrm{mg} \cdot / \mathrm{Kg} . \\
0.25 \mathrm{mg} \cdot / \mathrm{Kg} . \\
0.50 \mathrm{mg} \cdot / \mathrm{Kg} . \\
\text { Insulin }\end{array}$ & $\begin{array}{l}\text { NA } \\
\text { CE } \\
\text { RO } \\
\text { OL } \\
\text { NA }\end{array}$ & $\begin{array}{r}110 \\
200 \\
95 \\
95 \\
110\end{array}$ & $\begin{array}{r}100 \\
210 \\
95 \\
105 \\
105\end{array}$ & $\begin{array}{l}-10 \\
+\quad 10 \\
+\quad 10 \\
-\quad 5\end{array}$ \\
\hline $\begin{array}{l}3 \text { units } / \mathrm{Kg} \text {. } \\
10 \text { units } / \mathrm{Kg} \text {. } \\
15 \text { units } / \mathrm{Kg} \text {. }\end{array}$ & $\begin{array}{l}\text { CU } \\
\text { WA } \\
\text { XE }\end{array}$ & $\begin{array}{l}260 \\
130 \\
125\end{array}$ & $\begin{array}{l}250 \\
130 \\
145\end{array}$ & $\begin{array}{r}-10 \\
0 \\
+\quad 20\end{array}$ \\
\hline $\begin{array}{l}\text { Diphenylhydantoin } \\
20 \mathrm{mg} \text {./Kg. } \\
40 \mathrm{mg} \text {./Kg. } \\
20 \mathrm{mg} . / \mathrm{Kg} . \text { (3 days) } \\
\text { Chlorothiazide }\end{array}$ & $\begin{array}{l}\text { MT } \\
\text { WH } \\
\text { MO }\end{array}$ & $\begin{array}{l}130 \\
140 \\
140\end{array}$ & $\begin{array}{l}135 \\
135 \\
145\end{array}$ & $\begin{array}{l}+5 \\
\pm \quad 5 \\
+\quad 5\end{array}$ \\
\hline $\begin{array}{l}100 \mathrm{mg} . / \mathrm{Kg} . \\
200 \mathrm{mg} . / \mathrm{Kg} \text {. } \\
\text { Meralluride }\end{array}$ & $\begin{array}{l}\text { FA } \\
\text { OL }\end{array}$ & $\begin{array}{r}130 \\
95\end{array}$ & $\begin{array}{r}130 \\
95\end{array}$ & $\begin{array}{l}\mathbf{0} \\
\mathbf{0}\end{array}$ \\
\hline $\begin{array}{l}0.25 \mathrm{ml} . / \mathrm{Kg} . \\
0.4 \mathrm{ml} . / \mathrm{Kg} \text {. } \\
\text { Neostigmine }\end{array}$ & $\begin{array}{l}\text { XE } \\
\text { UG }\end{array}$ & $\begin{array}{l}125 \\
115\end{array}$ & $\begin{array}{l}135 \\
125\end{array}$ & $\begin{array}{l}+10 \\
+10\end{array}$ \\
\hline $\begin{array}{l}\text { Neostigmine } \\
0.1 \mathrm{mg} . / \mathrm{Kg} . \\
0.1 \mathrm{mg} . / \mathrm{Kg} .\end{array}$ & $\begin{array}{l}\text { UG } \\
\text { OL }\end{array}$ & $\begin{array}{r}115 \\
95\end{array}$ & $\begin{array}{r}95 \\
100\end{array}$ & $\begin{array}{l}-20 \\
+\quad 5\end{array}$ \\
\hline
\end{tabular}

* For each starred experimental group, a statistically significant change in half-time, on the average, was deter. mined using Wald's method of sequential analysis (8). The level of significance, $\alpha 1$, was .05 . The statistical tests were formulated so that a true mean sodium exchange half-time of 30 minutes (or more) would be detected with 95 per cent (or more) certainty. No statistical decision could be made about the remainder of factors.

$\dagger$ These dogs were not suitable for statistical analysis. 
sodium exchange time was due to the action of antidiuretic hormone or a nonspecific response due to the marked elevation in blood pressure, the effect of hypertension induced by norepinephrine on the exchange time was studied (see below).

2. Acetazolamide. The effect of acetazolamide on the sodium exchange time was determined in five dogs. The dosage varied between 30 and 120 $\mathrm{mg}$. per $\mathrm{Kg}$. of body weight. Acetazolamide, 100 $\mathrm{mg}$. per cent, was administered intravenously and the $\mathrm{Na}^{24}$ was injected five minutes later for the exchange study. In each case there was a marked increase in the sodium exchange time. The difference between the control and experimental halftimes ranged between 70 and 130 minutes, or 54 to 137 per cent greater than the control value. The average delay in the five dogs was $98 \mathrm{~min}$ utes. A formal statistical decision could be made with regard to the $120 \mathrm{mg}$. dosage only, but the data are interpreted to illustrate an effect at all dosage levels administered. There was no obvious correlation, however, between the dosage administered and the magnitude of the delay. The decrease in sodium exchange time cannot be correlated with a fall in the intracranial pressure. To the contrary, the intravenous administration of acetazolamide to anesthetized dogs resulted in an increase in CSF pressure. The effect of acetazolamide, $50 \mathrm{mg}$. and $100 \mathrm{mg}$. per $\mathrm{Kg}$. of body weight, 5.0 and $9.5 \mathrm{ml}$., on the CSF pressure was determined in two anesthetized dogs. The cisternal fluid pressure was recorded for a $40 \mathrm{~min}$ ute control period prior to the injection and for 160 minutes afterwards. The data are seen in Figure 2. The intracranial pressure in a control dog was also recorded. The intravenous administration of acetazolamide in these doses resulted in a rapid increase in intracranial pressure which was sustained over the 160 minute period. An injection of $10 \mathrm{ml}$. of normal saline to the control dog was without significant effect.

3. Intracranial mass lesion. A sustained increase in intracranial pressure lasting two to three weeks may be achieved by the placement of an epidural mass of bone wax and dental cement. The methods and resulting changes have been previously described in detail (10). Similar mass lesions were created in two dogs, each having had a control study one week prior to operation. Five

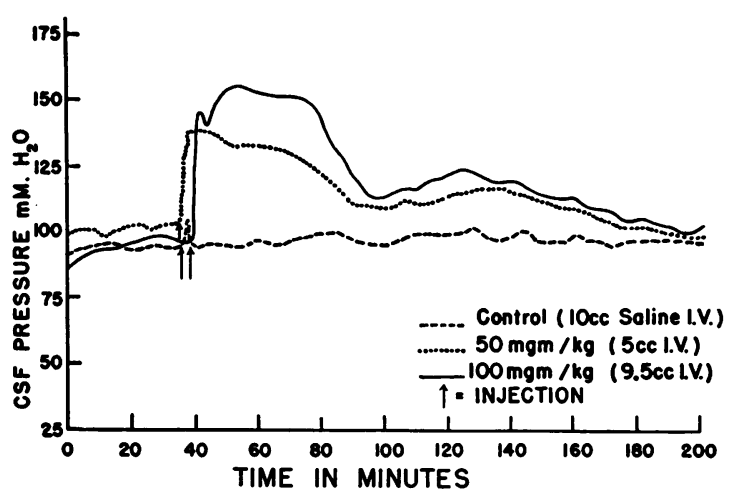

Fig. 2. Effect of Intravenous Acetazolamide on CSF Pressure

days postoperatively the radio-sodium studies were repeated. The initial pressures preoperatively in each were 90 and $110 \mathrm{~mm}$. water. The postoperative initial pressures were 260 and $240 \mathrm{~mm}$. of water, respectively. In Dog PL the control exchange time was 150 minutes, the postoperative time was 60 minutes. In Dog $\mathrm{CH}$ the control exchange time was 175 minutes, the postoperative time was 120 minutes.

4. Cerebrospinal fluid drainage. The effect of a marked decrease in intracranial pressure and CSF volume on the sodium exchange time was studied by the removal (gravity and gentle syringe drainage) of all the CSF that could be obtained over a five minute period. The initial pressures in two dogs were 80 and $85 \mathrm{~mm}$. water. A total of $7 \mathrm{ml}$. of CSF was removed from each animal. This usually results in an intracranial pressure of -50 to $-70 \mathrm{~mm}$. water (11). The tracer was then injected intravenously and the sodium exchange time determined in the usual manner. The control exchange time in the first dog was 175 minutes and in the second, $135 \mathrm{~min}$ utes. Following CSF drainage, the times were 90 and 110 minutes respectively.

\section{$I V$. Factors not altering sodium exchange time (see Table II)}

1. Fifty per cent sucrose. The rapid intravenous administration of 50 per cent sucrose results in a rapid fall in intracranial pressure (12). The effect of a hypertonic sucrose load on the sodium exchange time was determined as follows: Five experiments were performed in which 1.5 to 7.0 $\mathrm{ml}$. of 50 per cent sucrose per $\mathrm{Kg}$. of body weight 
was injected intravenously over a two minute period with the tracer dose of sodium in the same syringe. The sodium exchange time was performed in the usual manner. In no case was the sodium exchange appreciably different from the control value obtained at least seven days previously.

2. Five per cent dextrose in water. The rapid intravenous injection of large volumes of 5 per cent dextrose in water results in a marked increase in intracranial pressure. Previous study (10) of seven normal dogs revealed that a dosage of $50 \mathrm{ml}$. per $\mathrm{Kg}$. of body weight of 5 per cent dextrose in water, injected over a five minute period, resulted in a sustained increase in intracranial pressure. The average intracranial pressure was 77 per cent above the initial pressure over the first two hours and was still elevated at the end of four hours. The effect of such a water load upon sodium exchange was measured in three animals, each having had a previous control study. In each case, $50 \mathrm{ml}$. per $\mathrm{Kg}$. of body weight of 5 per cent dextrose in water was given intravenously over a five minute period. Immediately thereafter $\mathrm{Na}^{24}$ was given and the exchange determined in the usual way. In no case was the sodium exchange rate appreciably different from the control rate obtained at least seven days previously.

3. Steroids. The effect of desoxycorticosterone acetate (DCA), cortisone and adrenocorticotropic hormone $(\mathrm{ACTH})$ on the sodium exchange rate was also studied. In each dog a control study had been made at least one week earlier. The effect of DCA was studied after acute and chronic administration. In Dog BL $2 \mathrm{mg}$. of DCA per $\mathrm{Kg}$. of body weight was administered intramuscularly 20 hours and again 90 minutes prior to beginning the $\mathrm{Na}^{24}$ study. The control sodium exchange time was 145 minutes and the experimental time was 145 minutes revealing that this dosage of DCA did not alter sodium exchange. This dog was subsequently given DCA daily, 2 mg. per $\mathrm{Kg}$. of body weight intramuscularly for 11 days. Then the sodium exchange study was repeated, revealing a half-time of 140 minutes. Thus neither acute nor chronic administration of DCA appreciably altered the sodium exchange time. The prolonged administration of DCA did not appreciably alter the serum or CSF sodium concentration or the CSF potassium concentration. The serum potassium, however, fell from a control value of $4.1 \mathrm{mEq}$. per $\mathrm{L}$. to $2.7 \mathrm{mEq}$. per L.

The effect of cortisone was studied after acute and chronic administration. In Dog WO 7.5 $\mathrm{mg}$. of cortisone per $\mathrm{Kg}$. of body weight was given intramuscularly 20 hours and again 90 minutes prior to beginning the $\mathrm{Na}^{24}$ study. The control sodium exchange time was 170 minutes and the experimental time was 165 minutes, revealing that this dosage of cortisone did not alter sodium exchange. Another dog, BL, was given cortisone at the rate of $7.5 \mathrm{mg}$. per $\mathrm{Kg}$. of body weight daily for 14 days. The control exchange time in this animal was 150 minutes. Following the chronic cortisone administration, the half-time was 160 minutes. Thus neither acute nor chronic administration of cortisone appreciably altered the sodium exchange time.

The sodium exchange time was studied in one dog following intramuscular administration for 12 days of ACTH, 2 units per $\mathrm{Kg}$. of body weight per day. The control sodium exchange time was 215 minutes. The exchange time after ACTH was 235 minutes. Thus no appreciable change in the sodium exchange time was detected.

4. Ten per cent carbon dioxide in oxygen. The effect of inhalation of 10 per cent carbon dioxide in oxygen on the sodium exchange time was studied in three dogs. A cuffed endotracheal tube, 24 inches long, was inserted to the carina and the gas mixture supplied by a catheter inserted in the endotracheal tube to reach the carina. The gas mixture was supplied at a rate of $0.5 \mathrm{~L}$. per $\mathrm{Kg}$. of body weight per minute for 10 minutes, then the tracer dosage was given, and the gas mixture was continued for the following 225 minutes. The sodium exchange time was not appreciably affected in any case.

5. Norepinephrine. The effect of norepinephrine was studied in five dogs. These animals were given very large doses to maintain a mean blood pressure level elevation between 50 and 150 per cent above the control pressure. These acute systemic blood pressure elevations were paralleled by an elevation in CSF pressure. Norepinephrine bitartrate was given $(2 \mathrm{mg}$. norepinephrine bitartrate is equivalent to $1 \mathrm{mg}$. of norepinephrine base) by the intramuscular route, in 
dosages of $0.25 \mathrm{mg}$. or $0.5 \mathrm{mg}$. per $\mathrm{Kg}$. of body weight. Half the dose was given at zero time and one-quarter the dose at one hour and at two hours after the injection of the $\mathrm{Na}^{24}$. In no case was the exchange time appreciably altered by the sustained hypertension.

6. Insulin. The effect of large dosages of insulin on the sodium exchange time was determined in three dogs. Each dog received 3,10 or 15 units of crystalline insulin per $\mathrm{Kg}$. of body weight. The dogs were fasted for at least 12 hours prior to these experiments. The insulin was given intravenously 10 minutes before the injection of the $\mathrm{Na}^{24}$ for determination of the exchange time. In each case, there was no appreciable change in sodium exchange time.

7. Diphenylhydantoin. The effect of parenteral administration of diphenylhydantoin was determined in three dogs. In two dogs diphenylhydantoin, $20 \mathrm{mg}$. and $40 \mathrm{mg}$. per $\mathrm{Kg}$. of body weight, was injected intravenously five minutes prior to the injection of $\mathrm{Na}^{24}$ for the exchange study. In neither animal did the sodium exchange time differ significantly from the control value. In one dog diphenylhydantoin, $20 \mathrm{mg}$. per $\mathrm{Kg}$. of body weight, was injected intramuscularly for three days. Twenty-four hours after the third injection the sodium exchange study was repeated. The half-time did not appreciably differ from the control value previously obtained.

8. Chlorothiazide. The effect of chlorothiazide on the sodium exchange time was determined in two dogs. The animals were given $100 \mathrm{mg}$. and $200 \mathrm{mg}$. chlorothiazide intravenously 10 minutes prior to the injection of $\mathrm{Na}^{24}$ for the exchange study. In neither animal did the experimental half-time differ from the control value.

9. Meralluride. The effect of meralluride (Mercuhydrin ${ }^{\circledR}$ ) on the sodium exchange time was determined in two dogs. The dogs received meralluride by the intramuscular route 18 hours and 90 minutes prior to injection of $\mathrm{Na}^{24}$. The dogs were given $0.25 \mathrm{ml}$. and $0.4 \mathrm{ml}$. per $\mathrm{Kg}$. of body weight at each of these times. In neither case did the experimental half-time differ appreciably from the control value.

10. Neostigmine. The effect of neostigmine on the sodium exchange time was determined in two dogs. The dogs were both given intravenously 0.1 mg. per $\mathrm{Kg}$. of body weight of neostigmine methyl sulfate immediately preceeding the injection of $\mathrm{Na}^{24}$. No appreciable change in exchange time was noted.

\section{DISCUSSION}

The existence of a blood-CSF barrier to sodium has been verified by several workers $(5,6,13,14)$. Radio-sodium has been shown to reach equilibrium throughout the extracellular fluid within $25 \mathrm{~min}$ utes following intravenous injection (5), while the equilibrium time for CSF has been estimated at about 20 hours (13).

No statistical difference between the concentration of sodium in serum and CSF was detected, using the flame photometer, confirming previous reports in man (1) and dogs (2). However, a distribution ratio (CSF/serum) of 0.95 was calculated, correcting for differences in water content of the fluids. Davson (4) has reported differences in the distribution ratio in various species. It varied between 0.97 in a horse and 1.04 in guinea pigs, and was 0.975 in dogs. This interspecies variation has not been explained.

The rate of exchange of $\mathrm{Na}^{24}$ between the plasma and CSF is probably dependent on many independently operating permeability factors. The "barrier" anatomically must be considered to be composed of a number of structures, including the capillary endothelium, pia-glial membranes, choroid plexus, ependyma and arachnoid membrane, each of which probably has different permeability characteristics. The methods utilized in this study are considered to measure the net result of many factors affecting the exchange rate, and they do not throw light on the relative importance of the various membranes which constitute the barrier. The control studies have shown that the methods used have a satisfactory degree of reproducibility, though only major changes in exchange time can be detected. The marked variation of the control values in different dogs required that each dog be used as its own control. This variation is probably related to the anatomical variation among mongrel dogs. The importance of removing a standard amount of CSF at a standard time interval in determining the exchange time is demonstrated by noting the effect of spinal drainage. Thus a somewhat different exchange time would be expected if, for example, $1 \mathrm{ml}$. samples were removed at 30 minute intervals. This may par- 
tially explain differences in half-times as reported by various authors $(5,6,13)$.

A major limitation of the method used is the failure to take into account alterations in the volume of CSF. The exchange times in a given dog are comparable in various experimental situations only if the volume of CSF into which the tracer equilibrates remains constant. There is no satisfactory method for determining CSF volume in vivo-a major limiting factor in research with regard to the physiology of the cerebrospinal fluid. Thus, in the present experiments which record a marked decrease in exchange time following CSF drainage, it is impossible to state whether this represents increased permeability of the membranes secondary to the pressure change or whether the permeability is unchanged but the tracer is distributed into a much smaller volume of CSF. With this consideration in mind, the various experimental procedures and the possible interpretation of the data will be considered.

The administration of vasopressin resulted in a dramatic fall in sodium exchange time. This effect was not secondary to the hypertension that large doses of vasopressin produced, as even greater blood pressure elevation obtained with norepinephrine did not alter the sodium exchange time. Ussing has demonstrated that vasopressin strikingly increases the exchange of sodium and water across the frog epithelium (15). The hormone is considered to increase the size of individual pores or cellular channels in the membrane (16). Berliner, Levinsky, Davidson and Eden (17) also consider the effect of vasopressin on urinary concentration to result from the action of the hormone on tubular epithelial permeability. The effect of vasopressin on the blood-CSF barrier may be considered analogous to its effect on frog epithelial membranes, i.e., it facilitates ion and solvent exchange by increasing pore size or cellular channels in the membrane. It should be noted that this effect was obtained with amounts far exceeding the physiological range. The observation is of particular interest in that it suggests the hormone may affect mammalian membranes other than the renal epithelium. It is unlikely, however, that vasopressin has any importance physiologically in the control of the permeability of the blood-CSF barrier.

Acetazolamide, an inhibitor of the enzyme car- bonic anhydrase, is present in high concentration in the choroid plexus and brain as well as in red cells and kidney (18). The present studies have revealed the sodium exchange time to be greatly prolonged by acetazolamide, confirming a previous report of Davson and Luck (14). Carbonic anhydrase presumably facilitates sodium transport in tissues by making hydrogen ions available for exchange (19). Acetazolamide does not alter the distribution ratios of sodium, potassium and chloride between CSF and plasma (18), i.e., it decreases the rate of exchange of sodium but not its concentration. Thus sodium exchange between the plasma and CSF is in part dependent upon an enzyme which facilitates "active transport" of the ion. The cellular elements concerned with this secretory process probably include the choroid plexus as well as the cerebrum, both having a high concentration of the enzyme (18). In the present studies, acetazolamide administration resulted in a marked increase in CSF pressure. There is considerable divergence in the literature about the effect of acetazolamide on CSF pressure with reports of both increased (20-22) and decreased (18,23-25) CSF pressure resulting from administration of the drug. These differences depend in part upon the route of administration of the drug. The decrease in pressure, reported by Tschirgi, Frost and Taylor (24) after intravenous injection in artificially respired paralyzed cats, has been attibuted to the hypertonicity of the acetazolamide solution that was administered (26). It appears likely that intravenous administration results in an acute increase in intracranial pressure because of a local tissue increase in carbon dioxide tension which results in cerebrovascular dilatation (21). The explanation for the reported decrease in pressure with chronic oral administration in patients $(18,25)$ is not clear. It cannot be secondary to the decreased sodium exchange rate as the intracranial pressure may vary independently of the exchange rate, nor has there been any definite change reported in $\mathrm{pH}$, carbon dioxide, bicarbonate, or state of hydration to explain these observations. It appears likely that variation in the level of the CSF pressure is largely dependent upon acute vascular adjustments. Increased pressure is avoided with oral administration of the drug because sudden local increases in carbon dioxide tension probably do not occur. 
The data have demonstrated that $\mathrm{Na}^{24}$ exchange is more rapid in the presence of an epidural mass lesion associated with increased intracranial pressure. Since the presence of the intracranial mass results in a decreased intracranial volume, a decreased CSF volume may contribute to the apparent increase in sodium exchange. However, postmortem examination has revealed that the brain compression is marked and there is only a slight decrease in ventricular volume (10). It is likely that the increased permeability of the bloodbrain barrier adjacent to mass lesions, which is reflected by the increased permeability to radioiodinated serum albumin (27) and radio-phosphorus (28), is also partly responsible for the apparent increase in penetration of radio-sodium into the subarachnoid space. This may be considered analagous to the increase in protein content of the CSF commonly associated with mass lesions.

Major osmotic shifts did not affect the sodium exchange time. The large amounts of hypertonic sucrose administered reduced the intracranial pressure to about 50 per cent of the initial pressure (12). The rapid intravenous administration of 5 per cent dextrose in water, as given, resulted in a 77 per cent increase in intracranial pressure (10). While alterations in the volume of the CSF and of the fluid compartments of brain under these circumstances cannot be quantified, the sodium exchange appears to continue at a rate independent of the induced osmotic changes.

The effect of DCA, cortisone and ACTH on the sodium exchange time was studied in view of the effect of these compounds on brain function, notably convulsive threshold. Cortisone has been reported to lower, and desoxycorticosterone to raise, electroshock threshold in animals and man (29, 30). Woodbury, Timaris and Vernadakis have also reported that cortisone and DCA have opposing effects on sodium transport in rat brain (31). In the present study this phenomenon could not be demonstrated with regard to sodium exchange between serum and CSF. Davson has shown that radio-sodium reaches equilibrium in brain and CSF at the same rate (7), suggesting a common mechanism. The failure to obtain an effect in the present studies, similar to that described by Woodbury and associates (31), is not explained.
The administration of 10 per cent carbon dioxide in oxygen results in a marked increase in cerebral blood flow as well as a reduction in the $\mathrm{pH}$ of both plasma and CSF (32). The inhalation of 5 per cent carbon dioxide in oxygen has been reported to result in an increase in the rate of entry of radio-sodium into the CSF in human subjects (33). Inhalation of 50 per cent carbon dioxide has also been reported to result in an increase in brain intracellular sodium concentration in rats (34). In the present study, however, carbon dioxide inhalation did not affect the sodium exchange time.

The effect of large dosages of insulin was studied to detect whether profound hypoglycemia, with its associated change in brain function, might be reflected in a change in permeability of the bloodCSF barrier to sodium. Insulin hypoglycemia, which suppresses cerebral oxygen consumption and metabolism (35), did not affect the permeability of the barrier to sodium in the dosage used.

The effects of chlorothiazide and meralluride on sodium exchange were surveyed because both of these compounds have a profound effect on ion transport in the renal tubule, and it was considered reasonable to determine whether an effect on the blood-CSF barrier, particularly on the choroid plexus, could be detected. Chlorothiazide interferes with both sodium and chloride transport across the tubular epithelium (36), while the mercurials primarily effect chloride exchange, with the changes in sodium excretion generally considered as secondary phenomena (37). Neither of these drugs, however, had any detectable effect on sodium exchange in the present experiments.

Study of the effect of diphenylhydantoin on the sodium exchange time was prompted by Woodbury's report that diphenylhydantoin accelerates the active process controlling sodium movement across brain cells in rats (38). The present study has failed to reveal any effect of diphenylhydantoin on the sodium exchange between plasma and CSF.

Study of the effect of neostigmine on sodium exchange was prompted by the reports of Greig, Holland and Mayberry $(39,40)$ and Becker and Aird (41) implicating the acetylcholine-cholinesterase system in the control of cerebral permeability. The present study has failed to reveal any 
effect of neostigmine on the permeability of the blood-CSF barrier to sodium.

In summary, the present studies have revealed that the exchange of sodium between serum and CSF is strikingly constant in the face of a wide variety of pharmacological and physiological alterations. Thus, the following procedures failed to alter exchange: major osmotic shifts in either direction; large doses of cortisone, DCA and $\mathrm{ACTH} ; 10$ per cent carbon dioxide ; sustained hypertension induced by norepinephrine; insulin hypoglycemia; chlorothiazide; meralluride; and neostigmine. Sodium exchange was unchanged in the face of increased intracranial pressure induced by a load of 5 per cent dextrose in water or by norepinephrine, and was also unaffected by decreased intracranial pressure induced by a hypertonic sucrose load. Permeability to sodium was increased by extradural cerebral compression which has been considered above as a nonspecific effect. The apparent increase in exchange following drainage cannot be satisfactorily evaluated. The most striking effects have been obtained with acetazolamide and vasopressin. It is concluded that the acetazolamide effect proves that sodium exchange is in part dependent upon active transport of the ion. The vasopressin effect is interpreted as an example of the ability of antidiuretic hormone to increase membrane permeability in mammalian tissues other than the renal tubule.

These demonstrations of the relative constancy of sodium exchange supplement the previous studies of Cooper, Lechner and Bellet (2) which revealed that the ionic composition of CSF is maintained within very narrow limits despite major changes in the plasma electrolyte concentration. There is abundant evidence that the CSF is in dynamic equilibrium with the extracellular fluid of brain $(7,42)$. Recent evidence, largely derived with electron microscopy, throws doubt on the existence of an extracellular fluid space in brain and suggests that the extracellular fluid space represents the neuroglial cytoplasm (43). For the present, however, the extracellular fluid space, regardless of its true structural nature, is a useful concept. It appears likely that the bloodCSF barrier, anatomically a complex of membranes with selective permeability, functionally serves to stabilize the composition of the CSF and in turn the brain extracellular fluid, and so con- tributes to the maintenance of a stable internal environment for the central nervous system.

\section{SUM MARY}

The exchange of $\mathrm{Na}^{24}$ between plasma and cerebrospinal fluid (CSF) has been studied in anesthetized dogs. The average exchange time (half-time) in 27 normal dogs was $143 \pm 38$ minutes (S.D.). The administration of vasopressin resulted in a decrease in the exchange time. The intravenous administration of acetazolamide resulted in an increase in the exchange time and in a marked increase in intracranial pressure. Both increased intracranial pressure secondary to an epidural mass and decreased intracranial pressure secondary to CSF drainage resulted in a decrease in the exchange time. The exchange time was not affected by the following drugs and procedures: cortisone, desoxycorticosterone or corticotrophin, hypertonic or hypotonic intravenous solutions, 10 per cent carbon dioxide, norepinephrine, insulin hypoglycemia, diphenylhydantoin, chlorothiazide, meralluride or neostigmine. There was no direct correlation between change in intracranial pressure and the sodium exchange time. The significance of these data with regard to the blood-CSF barrier has been discussed.

\section{ACKNOWLEDGMENT}

The technical assistance of Miss Elizabeth Hiza and Mr. Ado Fleischmann and the cooperation of the Department of Radiological Research are gratefully acknowledged. The author wishes to express his appreciation to Phyllis B. Michelsen of the Division of Biostatistics of the Faculty of Medicine who provided advice and guidance in the statistical analyses.

\section{REFERENCES}

1. Bernstein, R. E. Flame analysis of sodium and potassium in small volumes of serum, heparinized plasma and cerebrospinal fluid. Amer. J. clin. Path. 1953, 23, 933.

2. Cooper, E. S., Lechner, E., and Bellet, S. Relation between serum and cerebrospinal fluid electrolytes under normal and abnormal conditions. Amer. J. Med. 1955, 18, 613.

3. Merritt, H. H., and Fremont-Smith, F. The Cerebrospinal Fluid. Philadelphia, Saunders, 1937, p. 28.

4. Davson, H. A comparative study of the aqueous humor and cerebrospinal fluid in the rabbit. $J$. Physiol. 1955, 129, 111. 
5. Wang, J. C. Penetration of radioactive sodium and chloride into cerebrospinal fluid and aqueous humor. J. gen. Physiol. 1948, 31, 259.

6. Olsen, N. S., and Rudolph, G. G. Transfer of sodium and bromide ions between blood, cerebrospinal fluid and brain tissue. Amer. J. Physiol. 1955, $183,427$.

7. Davson, H. Physiology of the Ocular and Cerebrospinal Fluids. Boston, Little, Brown and Co., 1956, p. 388.

8. Fisher, R. A. Statistical Methods for Research Workers, 11th ed. Edinburgh, Oliver and Boyd, 1950, p. 119.

9. Wald, A. Sequential Analysis. New York, John Wiley and Sons, 1948, p. 134.

10. Fishman, R. A. Effects of isotonic intravenous solutions on normal and increased intracranial pressure. Arch. Neurol. Psychiat. (Chicago) 1953, 70, 350.

11. Fishman, R. A. Unpublished observations.

12. Bullock, L. T., Gregersen, M. I., and Kinney, R. The use of hypertonic sucrose solution intravenously to reduce cerebrospinal fluid pressure without a secondary rise. Amer. J. Physiol. 1935, $112,82$.

13. Greenberg, D. M., Aird, R. B., Boelter, M. D. D., Campbell, W. W., Cohn, W. E., and Murayama, M. M. A study with radioactive isotopes of the permeability of the blood-cerebrospinal fluid barrier to ions. Amer. J. Physiol. 1943, 140, 47.

14. Davson, H., and Luck, C. P. The effects of acetazoleamide on the chemical composition of the aqueous humour and cerebrospinal fluid of some mammalian species and on the rate of turnover of ${ }^{2} \mathrm{Na}$ in these fluids. J. Physiol. 1957, 137, 279.

15. Ussing, $H$. $H$. Ion transport across biological membranes in Ion Transport Across Biological Membranes, H. T. Clarke, Ed. New York, Academic Press, 1954, p. 3.

16. Pappenheimer, J. R. Passage of molecules through capillary walls. Physiol. Rev. 1953, 33, 387.

17. Berliner, R. W., Levinsky, N. G., Davidson, D. G., and Eden, $M$. Dilution and concentration of the urine and the action of antidiuretic hormone. Amer. J. Med. 1958, 24, 730.

18. Birzis, L., Carter, C. H., and Maren, T. H. Effect of acetazolamide on CSF pressure and electrolytes in hydrocephalus. Neurology 1958, 8, 522.

19. Berliner, R. W., and Orloff, J. Carbonic anhydrase inhibitors. Pharmacol. Rev. 1956, 8, 137.

20. Knopp, L. M., Atkinson, J. R., and Ward, A. A., Jr. Effect of Diamox on cerebrospinal fluid pressure of cat and monkey. Neurology (Minneap.) 1957, 7, 119.

21. Atkinson, J. R., and Ward, A. A., Jr. Effect of Diamox on intracranial pressure and blood volume. Neurology (Minneap.) 1958, 8, 45.

22. Coppen, A. J., and Russell, G. F. M. Effect of intravenous acetazolamide on cerebrospinal-fluid pressure. Lancet 1957, 273, 926.
23. Kister, S. J. Carbonic anhydrase inhibition. VI The effect of acetazolamide on cerebrospinal fluid flow. J. Pharmacol. exp. Ther. 1956, 117, 402.

24. Tschirgi, R. D., Frost, R. W., and Taylor, J. L. Inhibition of cerebrospinal fluid formation by a carbonic anhydrase inhibitor, 2-acetylamino-1,3,4thiadiazole-5-sulfonamide (Diamox). Proc. Soc. exp. Biol. (N. Y.) 1954, 87, 373.

25. Elvidge, A. R., Branch, C. L., and Thompson, G. B. Observations in a case of hydrocephalus treated with Diamox. J. Neurosurg. 1957, 14, 628.

26. Bering, E. A., Jr. Problems of the dynamics of the cerebrospinal fluid with particular reference to the formation of cerebrospinal fluid and its relationship to cerebral metabolism. Clin. Neurosurg. 1958, 5, 77.

27. Chou, S. N., Aust, J. B., Moore, G. E., and Peyton, W. T. Radioactive iodinated human serum albumin as a tracer agent for diagnosing and localizing intracranial lesions. Proc. Soc. exp. Biol. (N. Y.) 1951, 77, 193.

28. Bakay, L. Dynamic aspects of the blood-brain barrier in Metabolism of the Nervous System, D. Richter, Ed. New York, Pergamon Press, 1957, p. 136.

29. Woodbury, D. M. Effect of hormones on brain excitability and electrolytes in Recent Progress in Hormone Research. New York, Academic Press, 1954, 10, 65.

30. Glaser, G. H. On the relationship between adrenal cortical activity and the convulsive state. Epilepsia III Series 1953, $2,7$.

31. Woodbury, D. M., Timiras, P. S., and Vernadakis, A. Influence of adrenocortical steroids on brain function and metabolism in Hormones, Brain Function and Behaviour, H. Hoagland, Ed. New York, Academic Press, 1957, p. 27.

32. Leusen, I. R. Acid-base equilibrium between blood and cerebrospinal fluid. Amer. J. Physiol. 1954, 176, 513.

33. Bourdillon, R. B., Fischer-Williams, M., Smith, H. V., and Taylor, K. B. The entry of radiosodium and of bromide into human cerebrospinal fluid. J. Neurol. Neurosurg. Psychiat. 1957, 20, 79.

34. Woodbury, D. M., Rollins, L. T., Gardner, M. D., Hirschi, W. L., Hogan, J. R., Rallison, M. L., Tanner, G. S., and Brodie, D. A. Effects of carbon dioxide on brain excitability and electrolytes. Amer. J. Physiol. 1958, 192, 79.

35. Himwich, H. E. Brain Metabolism and Cerebral Disorders. Baltimore, Williams and Wilkins Co., 1951, p. 451.

36. Bayer, K. H. The mechanism of action of chlorothiazide. Ann. N. Y. Acad. Sci. 1958, 71, 363.

37. Mudge, G. H., and Weiner, I. M. The mechanism of action of mercurial and xanthine diuretics. Ann. N. Y. Acad. Sci. 1958, 71, 344.

38. Woodbury, D. M. Effect of diphenylhydantoin on electrolytes and radiosodium turnover in brain 
and other tissues of normal, hyponatremic and postictal rats. J. Pharmacol. exp. Ther. 1955, 115, 74.

39. Greig, M. E., and Holland, W. C. Increased permeability of the hemoencephalic barrier produced by physostigmine and acetylcholine. Science 1949, 110, 237.

40. Greig, M. E., and Mayberry, T. C. The relationship between cholinesterase activity and brain permeability. J. Pharmacol. exp. Ther. 1951, 102, 1.

41. Becker, R. A., and Aird, R. B. Mechanisms influenc- ing the permeability of the blood-brain barrier. J. cell. comp. Physiol. 1955, 46, 127.

42. Davson, H. Some aspects of the relationship between the cerebrospinal fluid and the central nervous system in Ciba Foundation Symposium on the Cerebrospinal Fluid, Production, Circulation and Absorption. G. E. W. Wolstenholme and C. M. O'Connor, Eds. Boston, Little, Brown and Co., 1958, p. 189.

43. Windle, W. F., Ed. Biology of Neuroglia. Springfield, I1l., Charles C Thomas, 1958, pp. 85-161. 